
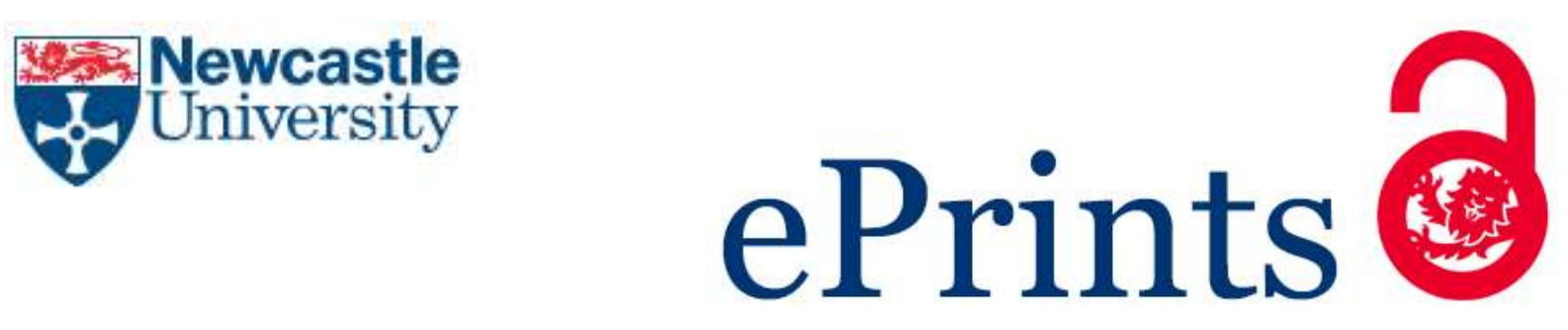

Anderson F. "A trail of drift and debris': Traces of Whitman in the correspondence art of Ray Johnson'. Journal of American Studies 2015, 49(1), 55-75.

\title{
Copyright:
}

The final version of this article is available from the following link:

http://dx.doi.org/10.1017/S002187581400125X

Date deposited:

$06 / 05 / 2016$

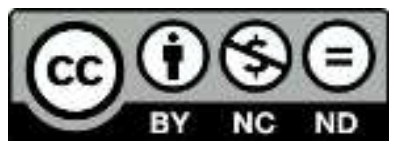

This work is licensed under a

Creative Commons Attribution-NonCommercial-NoDerivatives 4.0 International licence 


\title{
'A trail of drift and debris': Traces of Whitman in the correspondence art of Ray Johnson - Fiona Anderson
}

\begin{abstract}
In 1987, the artist Ray Johnson, 'leader' of the so-called New York Correspondence School, filled his mouth with Reese's Peanut Butter Cups and read some of Walt Whitman's musings on the nature of correspondence in a performance that Johnson dubbed 'Smile.' An example of what Johnson termed his 'nothings,' 'Smile' took place in an empty ATM vestibule on Long Island, the nostalgic 'Paumanok' of Whitman's poetry. Johnson's performance both elevated and mocked Whitman's equally personal approach to the art and practice of correspondence. By invoking Whitman and his thoughts on correspondence, Johnson was keen to respond to descriptions of him as "Dada Daddy" to a younger generation of correspondence artists. Johnson's performance looked not so much to elevate his own ephemeral correspondence art, but to foster a reappraisal of Whitman that considered the ephemerality of his poetic method and opened up a queer line of communication and anti-teleological influence that would disrupt Johnson's own artistic reception. This article examines 'Smile' as an (auto)biographical performance that simultaneously clarifies and clouds the creative methodologies of Johnson and Whitman; declaring Whitman's influence on the irreverent Johnson while rejecting the restrictions of a chronological chain of influence, much as Johnson's earlier mail art had done.
\end{abstract}

\section{'A trail of drift and debris': Traces of Whitman in the correspondence art of Ray Johnson}

In the evening of August 20th 1987, the artist Ray Johnson, reluctantly anointed and historically elusive leader of the so-called New York Correspondence School - or mail art movement - of the early 1960s, entered an empty ATM vestibule in Huntington, Long Island, filled his mouth with Reese's Peanut Butter Cups and, with a copy of Walt Whitman's Camden Conversations, an abridged edition of Horace Traubel's With Walt Whitman in Camden, a four volume collection of conversations with the elderly poet at his New Jersey home, began to read from some of the Whitman's musings on the nature of correspondence, laughing as the candy cups melted and broke apart, obscuring his reading, in a performance that Johnson dubbed 'Smile' [Figure 1]. An example of what the artist had earlier termed 'nothings' - a witty commentary on the artist Allan Kaprow's almost contemporary performance 'happenings' and the composer John Cage's creative engagement with Taoism and Zen Buddhism - the event was recorded by the filmmaker Nick Maravell, a friend of Johnson's, who constituted as the performance's only 'audience.'

Johnson's performance has emerged from critical obscurity in part as a consequence of the work of his friend and correspondent, the art historian William S. Wilson. Wilson's brief analysis of 'Smile' in an interview in 2000 characterised the piece as "[containing] an apologia for [Johnson's] art, and a theory of knowledge"; an intentionally crude allegory of his peculiar practice. ${ }^{1}$ "Ray's reading was not for a moment disgusting," Wilson argued:

[t]he words were unintelligible until they gradually cleared. It was a demonstration that Ray sees, reads and knows more than can be communicated in his art which mashes ideas and imag-

${ }^{1}$ John Suiter, 'Last Post,' Independent, 4 June 2000, n.p. 
es, even as he was mashing the peanut butter cups with his mouth. [...] If he knows more than we can immediately understand until he has mashed something, what else does he know that we don't know, and that we can correctly perceive only sections of ? ${ }^{2}$

By comparing Johnson's exuberant performance with Whitman's own thoughts on correspondence, this article posits 'Smile' as a complex (auto)biographical performance that declares Whitman's influence on the irreverent Johnson, while rejecting the restrictions of a linear narrative of influence. An exploration of the rich visual and textual correspondences encoded within Johnson's letters and performances suggests, instead, that correspondence with and within Whitman's practice was a performative practice of backward glances,' of coded homosexual desires and hidden lives, and offered both Whitman and Johnson a queer mode of making counter-histories. ${ }^{3}$

Whitman was born in Huntington in May 1819, and the ATM vestibule appropriated as an impromptu performance space by Johnson and Maravell stood directly across the street from the building where in 1839 Whitman had founded the Long Islander newspaper. Of this period, Whitman later wrote: "long before Leaves of Grass - before it was thought of even [-] I was a mere boy then - [the Long Islander] was in fact my boyish exuberance put into concrete manifestation," a newspaper which was "non-partisan, no party affiliation, independent - not neutral travelling its own road." Long Island was, too, the nostalgic Paumanok of Whitman's poetry, described in his essay 'A Backward Glance O'er Travelled Roads' (1888) as a space for contem-

\footnotetext{
2 Suiter, n.p.

${ }^{3}$ See Mark Turner, Backwards Glances: Cruising Queer Streets in London and New York (London: Reaktion Books, 2003) and Walt Whitman, 'A Backward Glance O'er Travelled Roads,' Complete Poems (London: Penguin, 2004), 569 - 584.
}

In suggesting Whitman and Johnson's practices as a kind of queer poetics and model for counterhistories, I am invoking an interpretation of the term 'queer' that derives from the writings of Eve Kosofsky Sedgwick, Judith Butler, David Halperin and others. As Butler notes, queer is "a term that signaled degradation [and] has been been turned [...] to signify a new and affirmative set of meanings." (Judith Butler, Bodies that Matter (London: Routledge, 1993), 169.) For Halperin, queer is thus "by definition whatever is at odds with the normal, the legitimate, the dominant. There is nothing in particular to which it necessarily refers. It is an identity without an essence. 'Queer' then, demarcates not a positivity but a positionality vis-à-vis the normative." (David Halperin, Saint Foucault: Towards a Gay Hagiography (Oxford: Oxford University Press, 1997), 62.) For Sedgwick, queer theory is a means of resisting a "minoritizing versus universalizing" view of sexual definition, "between seeing same-sex object choice on the one hand as a matter of liminality or transitivity between genders, and seeing it on the other hand as reflecting an impulse of separatism - though by no means necessarily political separatism within each gender," creating a lasting incoherence "between seeing homo/heterosexual definition on the one hand as an issue of active importance primarily for a small, distinct, relatively fixed homosexual minority ... [and] seeing it on the other hand as an issue of continuing, determinative importance in the lives of people across the spectrum of sexualities." (Eve Kosofsky Sedgwick, The Epistemology of the Closet (Berkeley: University of California Press, 1990), 1.) ${ }^{4}$ Gary Schmidgall, Intimate with Walt: Selections from Whitman's Camden conversations with Horace Traubel, 1888 - 1892 (Iowa City: University of Iowa Press, 2001), 44: emphasis added. 
plation and his consideration of Leaves of Grass as "a candidate for the future," but also as a venue for the "garrulous talk, thoughts, [and] reminiscences" that he similarly enjoyed. ${ }^{5}$ As Traubel recalled, "W[alt][loved] to receive letters," and Gary Schmidgall notes in his study of Traubel's interviews that "the arrival of mail was perhaps second only to the arrival of Horace himself at Mickle Street [Whitman's Camden home]." 6 Yet both Traubel and Schmidgall make clear that the poet did not regard himself as "much of a correspondent."7 As Johnson read as part of his performance at Huntington:

[I] never was, always wrote when I had something definite to say but never for the sake of writing, never for the sake of keeping up what is called a correspondence. Such correspondence as that of Emerson and Carlyle would be impossible to me, though I see it is all right in itself and for them. ${ }^{8}$

In their conversations at Camden, as numerous "avowal letters" from fond readers arrived and were read aloud, Whitman was quick to convey to Traubel that he considered correspondence to be "a matter of taste, of temperament. I don't believe I ever wrote a purely literary letter, ever got to discussing books or literary men or writers or artists of any sort in letters: the very idea of it makes me sick. I like letters to be personal - very personal - and then stop." ${ }^{10}$ In Johnson's performance, Whitman's words are mashed up along with the peanut butter cups, collaged in a fragmented rendition of his late reflections that puns on the poet's musings on 'taste' and sickness; a queer homage in which Johnson's exuberant misbehaviour hints at the more disagreeable sense of his own artistic (mis)representation by later followers of the Correspondence School, namely artists groups and art collectives such as General Idea and the Image Bank - the Torontobased creators of File and Vile megazines - for whom he had come to be known, much to his chagrin, as mail art's 'Sugar Dada.'11 "“I was the first and the father of mail art' [...] I'm sick of hearing that, it's just such a cliché." Johnson told Henry Martin, even as he encouraged General Idea to engage in New York Correspondence School mailings. ${ }^{12}$ Johnson first used the title 'Smile' in an interview in 1978, in which he spoke of reacting to:

5 Walt Whitman, 'A Backward Glance O’er Travelled Roads,' 583.

'Paumonok' was the Native American name for Long Island.

${ }^{6}$ Schmidgall, 123.

${ }^{7}$ Horace Traubel, With Walt Whitman in Camden, March 28 - July 141888 (New York: Mitchell

Kennerley, 1915), 137.

8 Traubel, 137.

${ }^{9}$ Schmidgall, 123.

10 Traubel, 137: emphasis added.

${ }^{11}$ For further information on General Idea and Image Bank, see Gregg Bordowitz, General Idea: Imagevirus (MIT Press/Afterall: 2010); ed. Frédéric Bonnet, General Idea: Haute Culture: a Retrospective, 1969-1994 (JRP Ringier, 2011)

12 Henry Martin, 'Should an eyelash last forever? An interview with Ray Johnson,' Donna de Salvo, and Catherine Gudis, eds., Ray Johnson: Correspondences (Columbus, OH: Wexner Center for the Arts, 1999), 187. 
the phenomenon of File magazine which is an offshoot of the correspondence school, not that I published a magazine. In labelling me Dada Daddy they have in every issue a picture of me as their father, this is what they proclaim. But File magazine was then parodied by Vile magazine in San Francisco and since File was a parody of Life and Time and Vile a parody of File, I then invented Smile magazine. ${ }^{13}$

No trace of Smile magazine appears to exist. It seems to have been, like 'Smile,' an ephemeral 'nothing.' Not only did Johnson reject the role of father; he rejected the implication that correspondence art had been intellectually birthed by any artist at all. For critic Edward Plunkett, as for Johnson, correspondence art was "an ephemeral, evanescent business that [disdained] description" and chronological cohesion. ${ }^{14}$ Plunkett saw Johnson as the "central figure" of this evanescent school, but stopped short of anointing him as its "founder."15

Whitman, too, as he sat "gossiping in the early candle-light of old age" with Traubel and others, was equally sceptical of any linear narrative history of his work. ${ }^{16}$ In 'Starting from Paumonok,' as in 'Crossing Brooklyn Ferry,' Whitman imagined a future reader "with eyes retrospective towards me," "projected through time [...] an audience interminable." 17 In "A Backward Glance O'er Travelled Roads' he emphasised that, rather than a chain of teleological influence, "[p]erhaps the best of songs heard, or of any and all true love, or life's fairest episodes [...] is the résumé of them, [...] How the soul loves to float amid such reminiscences!"18 This essay served as a preface to Whitman's penultimate published book of poems, November Boughs, and intentionally disrupted any homogeneous interpretation of the man or his work. It was a performative disavowal of literary lineage and poetic teleology, a practice of Whitman's that was perhaps most apparent in his continual reworking of Leaves of Grass, assisted by Traubel, until the poet's death in March 1892. "After completing my poems," Whitman wrote,

I am curious to review them in the light of their own (at the time unconscious, or mostly unconscious) intentions, with certain unfoldings of the thirty years they seek to embody. These lines, therefore, will probably blend the weft of first purposes and speculations, with the warp of that experience afterwards, always bringing strange developments. ${ }^{20}$

13 Diane Spodarek and Randy Delbeke, 'Detroit Artist Monthly 1978: An Interview with Ray Johnson,' http://www.jpallas.com/hh/rj/DAMintervw-RayJ.html, accessed 18 March 2010.

14 Edward Plunkett, 'Send Letters, Postcards, Drawings and Objects...' Art Journal (Spring 1977), 233.

15 Plunkett, 233.

${ }^{16}$ Whitman, 'A Backward Glance O’er Travelled Roads,' 569.

17 Whitman, 'Starting from Paumonok,' 51: emphasis added

"It avails not, time nor place - distance avails not, / I am with you, you men and women of a generation, or / ever so many generations hence.” Whitman, 'Crossing Brooklyn Ferry,' Complete Poems, 191.

18 Whitman, 'A Backward Glance O’er Travelled Roads,' 567: emphasis added.

19 Justin Kaplan, Walt Whitman: A Life (New York: Simon and Schuster, 1979), 51.

20 Whitman, 'A Backward Glance O’er Travelled Roads,' 569: emphasis added. 
In January 1892, the following announcement appeared in the New York Herald: "Walt Whitman wishes respectfully to notify the public that the book Leaves of Grass, which he has been working on at great intervals and partially issued for the past thirty-five or forty years, is now completed, so to call it, and he would like this new 1892 edition to absolutely supersede all previous ones. Faulty as it is, he decides it as by far his special and entire self-chosen poetic utterance." 21 Like Johnson, Whitman was resistant to a teleological narrative of his practice that might solidify his influence and limit interpretations of his poetry.

The 'New York Correspondence School' was a moniker coined in 1962 by the artist Edward Plunkett to describe the collages that Johnson had been working on since the late 1950s; "combining," as Robyn Laba has noted, "a reference to the New York School, identified with abstract expressionist [sic] painting [...], with an allusion to introductory art courses offered through the mail." 22 Johnson worked on small collages that he termed 'moticos,' that incorporated materials and imagery from the worlds of contemporary advertising and popular entertainment, developed and defaced by his distinctive marker drawings and humorous commentary, and often directed at, or 'addressed' to, a particular friend or celebrity. Throughout the 1960s, Johnson sent out mailings that referred to non-existent fan clubs and seating plans for events that featured dead or fictitious film stars. In an interview with Henry Martin in 1982, Johnson described the postal dimensions of his work as a direct rejection of the traditionally sanctioned spaces of artistic production and display. "I send out monthly newsletters," he wrote, "about the work that I am doing which takes the place of formal exhibitions. The works cannot be exhibited in the usual way, because they continually change, like the news in the paper or the images on a movie screen." 23 The medium of collage mirrored Johnson's method of circulation; a "non-linear, stream-ofconsciousness stance," that as Donna De Salvo has argued, "allowed the random, coincidental, and ephemeral to occupy the same plane of critical consideration as more traditional and universal concerns." 24 Splicing together handwritten phrases, text clipped from newspapers, tabloid photographs and newspaper advertisements, the medium of correspondence and of collage allowed Johnson to operate in the incommensurable space between word and image, that zone which, for WJT Mitchell, "like the concepts of race, gender, and class in the study of culture, designates multiple regions of social and semiotic difference that we can live neither with nor without, but must continually reinvent and renegotiate." 25

In early 'motico' works like 'Elvis \#2' (1956-7) [Figure 2], Johnson satirised the 'action painting' practices of the Abstract Expressionists, turning an appropriated photograph of Elvis Presley into an image of Oedipus, red paint seeping from his eyes in an acerbic reference to the painterly 'drips' of Jackson Pollock, who had been killed in a car accident the previous summer. In collages such as this, Johnson addressed the dominance of Pollock, contesting his legacy humorously

21 Justin Kaplan, Walt Whitman: A Life. New York: Simon and Schuster, 1979. 51

22 Robyn Laba, 'A Short History of the New York Correspondence School and the Early Canadian Mail Art Network,' The Art of Ray Johnson and the New York Correspondence School (Morris and Helen Belkin Art Gallery: University of British Columbia Press, 2001)

${ }^{23}$ Martin, 1999, 184 - 185.

24 Donna de Salvo, 'Correspondences,' de Salvo and Gudis, 15.

${ }^{25}$ WJT Mitchell, 'Word and Image,' in ed. Robert S. Nelson, Richard Shiff, Critical Terms for Art History (University of Chicago Press, 2003), 60. 
in the years immediately following his death. His move into performance-based work, his socalled 'nothings,' in the early 1960s owes much to Allan Kaprow's interpretation of Pollock's painting practice in his early Happenings, The notion of nothingness was, after all, an important dimension of the practice of these Happenings. "Young artists of today," Kaprow wrote in his essay 'The Legacy of Jackson Pollock' (1958):

need no longer say, 'I am a painter' or 'a poet' or 'a dancer.' They are simply 'artists.' All of life will be open to them. They will discover out of ordinary things the meaning of ordinariness. They will not try to make them extraordinary but will only state their real meaning. But out of nothing they will devise the extraordinary and then maybe nothingness as well. ${ }^{26}$

Although Johnson's use of the term 'nothing' was a humorous play on Kaprow's earnest manifesto, rather than a critique of his theory, the artists' distinct responses to the critical dominance of Abstract Expressionism in the late 1950s illuminates their divergent attitudes toward artistic influence and modes of conceptualising art historical lineage. Kaprow wrote that he found in Pollock's work "the possibility of an astounding freshness, a sort of ecstatic blindness," an unintentionally Oedipal phrasing that Johnson would surely have enjoyed. $\mathrm{x}^{27}$ Elsewhere in 'The Legacy of Jackson Pollock,' Kaprow explained that his Happenings drew from what he termed the "spatial extension" of Abstract Expressionist painting, an identification with the elevation of "process" over subject matter that, for him, suggested that after Pollock, artists should "give up the making of paintings entirely" and move into performance. ${ }^{28}$ This characterisation contrasts with the treatment of Abstract Expressionism in the writings of Clement Greenberg. In 'Modernist Painting' (1961), Greenberg emphasised that "the ineluctable flatness" of a painting, viewed primarily as a two-dimensional surface, was "the only condition painting shared with no other art," 29 emphasising painting's disciplinary distinction from theatre or sculpture "not in order to subvert it but in order to entrench it more firmly in its area of competence." 30 By focusing on the medium's unique qualities of flatness Greenberg argued, Modernist painters like Pollock eradicated any existing traces of illusionism from the practice of painting, which, he argued, was a problematic consideration "shared not only with the theatre, but also with sculpture." 31 "Whereas one tends to see what is in an Old Master before one sees the picture itself," Greenberg argued, "one sees a Modernist picture as a picture first. This is, of course, the best way of seeing any kind of picture [...] the only and necessary way." 32 Kaprow's conceptualisation of Pollock is much closer to Harold Rosenberg's description of the practices of Pollock and Willem de Kooning. The space of the painting, Rosenberg argued, is not a transcendental zone of self-critique, as it was for Greenberg, but "an arena in which to act [...]. What was to go on the canvas was not

\footnotetext{
${ }^{26}$ Allan Kaprow, The Legacy of Jackson Pollock. Essays on the Blurring of Art and Life (Berkeley; Los Angeles, CA: University of California Press, 1993), 9.

27 Kaprow, 1.

${ }^{28}$ Kaprow, 6.

${ }^{29}$ Clement Greenberg, 'Modernist Painting' in ed.John O'Brian, Clement Greenberg: The Collected Essays and Criticism, Volume 4: Modernism with a Vengeance, 1957-1969 (Chicago; London: Chicago University Press, 1993), 87.

${ }^{30}$ Greenberg, 85.

${ }^{31}$ Greenberg, 87.

${ }^{32}$ Greenberg, 87.
} 
a picture but an event. The painter no longer approached his easel with an image in his mind; he went up to it with material in his hand to do something to that other piece of material in front of him. The image would be the result of this encounter." 33 In opposition to Greenberg, Rosenberg emphasises that this kind of active painting cannot be subject to value judgment: "[a]n action is not a matter of taste. You don't let taste decide the firing of a pistol." ${ }^{34}$ For Rosenberg, the action of Abstract Expressionism opened up a dialogue between the spheres of 'art' and 'life,' kept apart in Greenberg's conception of "successful" Modernist painting. ${ }^{35}$ Similarly, Kaprow argued that "Pollock, as I see him, left us at the point where we must become preoccupied with and even dazzled by the space and objects of our everyday life, either our bodies, clothes, rooms, or, if need be, the vastness of Forty-second Street." ${ }^{36}$

What precedents Kaprow uncovered in the painting of Jackson Pollock, Johnson found in the quotidian practice of correspondence, employed both literally and allegorically. He distanced himself from the "ineluctable flatness" of painting through correspondent paper folds, repetitious cutting and pasting from magazines and commercial mailings, decidedly non-transcendental and critically derided (by Greenberg at least) kitsch cultural sources. ${ }^{37}$ In Johnson's work, correspondence referred to both "content (similarity) and method (epistolary intercourse)," a limitless and playful model that invoked Baudelaire's notion of equivalences, and consequently the exquisite corpse games of the Surrealists, in which multiple artists collaborated in constructing sentences or drawings on a single sheet of paper, repeatedly folded down each to hide the preceding contribution and enhance the mysterious form of the final 'corpse,' and the paper collage and photomontage practices of Dada artists in Zürich and Berlin. ${ }^{38}$ While Kaprow, in his writings and in early works like Eighteen Happenings in Six Parts (1958), sought to "get rid of the usual idea of 'Form," epitomised by Clement Greenberg's elevation of the painterly qualities of flatness and abstraction, and his championing of Pollock as "the greatest painter of his generation," Kaprow mobilised similar familial metaphors as he sought connection with Pollock to establish aesthetic parentage for the nascent Happenings scene. ${ }^{39}$ While, as WJT Mitchell notes, "one of the central impulses of artistic modernism in the twentieth century has been, as Clement Greenberg argued, to explore the distinctness and difference of verbal and visual media, seeking a purely optical painting and a purely verbal poetry, the larger culture has been dominated by the

${ }^{33}$ Harold Rosenberg, 'The American Action Painters' in ed. Sally Everett, Art Theory and Criticism: An Anthology of Formalist, Avant-Garde, Contextualist and Post-Modernist Thought (Jefferson, NC: McFarland, 1995), 57.

${ }^{34}$ Rosenberg, 64.

${ }^{35}$ Greenberg, 71.

${ }^{36}$ Kaprow, 7.

${ }^{37}$ See Greenberg, 'Avant-Garde and Kitsch' in eds. Charles Harrison and Paul Wood, Art in Theory, 1900 - 2000: An Anthology of Changing Ideas (Blackwell, 2003), 539 - 541.

38 William S. Wilson, 'Ray Johnson: NY Correspondence School,' Art and Artists 1 (April 1966), 54-57.

${ }^{39}$ Clement Greenberg, 'Review of Exhibitions of Mondrian, Kandinsky, and Pollock; of the Annual Exhibition of the American Abstract Artists; and of the Exhibition European Artists in America,' in ed. John O'Brian, The Collected Essays and Criticism, Volume 2: Arrogant Purpose, 1945-1949, 16: emphasis added. 
aesthetics of kitsch, which freely mixes and adulterates" the words and images of mainstream media production. ${ }^{40}$

What was particularly appealing to Johnson about the transient and kitsch media of correspondence and collage was its inherent formal potential for complicating any institutionally sanctioned artistic lineage, such as that espoused by Greenberg, epitomised in his embrace of Walt Whitman's high-spirited poetic praxis in 'Smile.' In a small correspondence piece sent to William S. Wilson in 1973, Johnson attached an advertisement for a boy's 'Action Jackson' doll to a card onto which he had written 'Jackson Pollock 1912 - 1956' and drawn an oversized penis onto the image of the doll. 'This squirrels got nuts!' he added. The extent of Johnson's resistance to this kind of generational art history and the tendency towards paternal metaphors is typified by his ambivalent responses to institutional recognition. In September 1970, he was the subject of a retrospective exhibition at the Whitney Museum of American Art in New York. Instead of simply collating his earlier work, Johnson willfully complicated the curatorial process by initiating a vast correspondence piece with a number of noted New York art world figures. Over one hundred correspondents, including the artists Yoko Ono and James Rosenquist, responded to Johnson's request for friends to send small pieces to the show's curator Marcia Tucker, concluding with a postcard from Johnson himself that read, 'Dear Whitney Museum, I hate you, Love Ray Johnson. ${ }^{41}$ Similarly, in 1972, two years after the Whitney retrospective, Johnson was asked to exhibit at the Betty Parsons Gallery on 57th Street, and created 'Ray Johnson's History of the Betty Parsons Gallery,' a collection of collages of the gallery's represented artists that refuted chronological interpretation by being impossible to view in any decipherable lineage. The critic Lawrence Alloway noted in his review of the Parsons show in The Nation that Johnson explained the piece simply as "name dropping." 42

Wordplay and 'name dropping' appear throughout Johnson's mailings: puns on television host David Letterman, for example, and on the acronymic and homonymic similarities between the names of the poet Marianne Moore and the actress Marilyn Monroe. Almost no name, no image, was referenced in Johnson's work arbitrarily. His 'nothings,' first staged in July 1960, punned not only on the work of Allan Kaprow, but on the Taoist writings of John Cage, whom he met at Black Mountain College in 1948, and after whom he affectionately termed the so-called Correspondence School 'Buddha University' and the 'Taoist Pop School.' "I have nothing to say," Cage asserted in his lecture 'Composition as Process' in 1958, "and I'm saying it." 43 In one such 'nothing,' guests arrived to find Johnson pushing a piano across the room - when they offered to assist, he refused, and eventually left. Exalting the idea of nothingness also allowed Johnson to ensure that his works could have multiple, even infinite, meanings, playing with the "open-ended and fluid" form of Happenings and Kaprow's exaltation of "ordinariness," but, further, punned on the Pop detachment of his contemporary Andy Warhol: "If you want to know all about Andy Warhol," the artist later said, "just look at the surface of my paintings and films and me, and

\footnotetext{
40 WJT Mitchell, 'Word and Image,' 54.

${ }^{41}$ Alex Sainsbury, Ray Johnson. Please Add to \& Return, Raven Row. Web. 18 March 2010

42 Lawrence Alloway, 'Ray Johnson,' Art Journal (Spring 1977), n.p.

${ }^{43}$ John Cage, 'Composition as Process' in Silence: Lectures and Writings (Middletown, CT: Wesleyan University Press, 1961), 61.
} 
there I am. There's nothing behind it."44 Johnson, by contrast, was more readily concerned with a poetics of correspondence and nothingness in the ontological mode of Jean-Paul Sartre, resistant to historicisation and commodification; a no-thingness. ${ }^{45}$ In this way, his recourse to nothingness suggested, too, that a cohesive Correspondence School never existed, and thus could not be chronologically historicised: "a 'school,' [...] 'mail art,' [...] I never used those terms at all," Johnson argued. ${ }^{46}$ When Johnson did, in fact, use such a term, it was in a note declaring its death to the New York Times in April 1973; a 'dead letter,' only to be resurrected two months later. In a note to David Bourdon, Johnson remarked that the Correspondence School "has no history, only

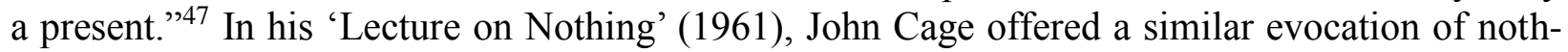
ingness as an approach to creative production that rejected historicisation and poetic teleology, offering the present as a non-commodifiable time and space without ownership, with aesthetic value as "no thing.' "Our poetry now," Cage asserted, "is the realisation that we possess nothing. Anything therefore is a delight (since we do not possess it) and thus need not fear its loss. We need not destroy the past: it is gone; at any moment it might reappear and seem to be and be the present. Would it be a repetition? Only if we thought we owned it, but since we don't, it is free and so are we." 48

Johnson later described his statement as "a pun, of course, on 'present' as a gift, and 'present' as now, a pun on my own way of giving information and objects or whatever in letter form." ${ }^{49}$ Lewis Hyde, in The Gift: Imagination and the Erotic Life of Property, published four years prior to Johnson's performance, examines the complex social and economic relations engendered by the giving of gifts in a range of socio-political contexts. All aesthetic activity, he argues, is a kind of gift-giving, because it consists of the sharing of the artist's "inner gift" with an audience who are moved by such creative "endowments." 50 "[I]n the essential commerce of art," Hyde states, "a gift is carried by the work from the artist to his audience" in a manner that exceeds its economic value or commodity status. ${ }^{51}$ The gift is awarded this authority precisely because there is no assurance of anything commodifiable in return. "Any exchange," Hyde argues, "be it of ideas or of goats, will tends towards gift if it is intended to recognize, establish or maintain community." ${ }^{, 53}$ By the same token, the "conversion of gifts to commodities can fragment or destroy such a group." ${ }^{54}$ Thus, a present (the gift) exists continually in the present (the continual now) because

\footnotetext{
${ }^{44}$ Gretchen Berg, 'Andy: My True Story,' Los Angeles Free Press (March 17, 1963), 3.

${ }^{45}$ See Jean-Paul Sartre, Being and Nothingness (London: Routledge, 2003 [1943])

${ }^{46}$ Martin, 188.

${ }^{47}$ Martin, 188.

${ }^{48}$ Cage, 'Lecture on Nothing,' in Silence: Lectures and Writings (Middletown, CT: Wesleyan

University Press, 1961), 110.

${ }^{49}$ Martin, 188.

${ }^{50}$ Lewis Hyde, The Gift: Imagination and the Erotic Life of Property (New York: Vintage
} Books, 1983), xii.

See also Marcel Mauss, The Gift: Forms and Functions of Exchange in Archaic Societies (New York: W. W. Norton, 1967)

${ }^{51}$ Hyde, xiii.

${ }^{52}$ Hyde, xvii.

53 Hyde, 78.

${ }^{54}$ Hyde, 80. 
its value is wholly social. Viewing his own correspondence practice in terms of a punned 'present,' Johnson enacts a similar process of social generosity across time; literary and artistic exchanges proffered to correspondents both living and dead, without the expectation or possibility of reciprocity. Thus, Whitman is the ideal correspondent in Johnson's conception of the 'erotic life of property' and its temporal reciprocity, since he is always already in dialogue with his future readers. In 'Crossing Brooklyn Ferry,' Whitman called out to readers, "you men and women of a generation, or ever so many generations hence." 55 "It avails not, time nor place," he announces, "- distance avails not, / I am with you." ${ }^{56}$ An exchange with readers across time and place is made possible through the continual presentness of the poem, read and re-read, by "ever so many generations hence." 57 The giving of presents - literary, aesthetic, erotic - by both Johnson and Whitman, engenders a non-chronological space-time of creative exchange that offers temporal union, but does not demand reciprocity.

Correspondence was, Johnson insisted, "a life necessity," a vital communication with friends rather than a wholly intellectual effort, and later claims of his creative influence coincidental: "I have written a lot of letters," he told Henry Martin, "and given away a lot of material and information, and it has been a compulsion. And as I have done this, it has become historical. It's my résumé, it's my biography, it's my history, it's my life." 58 Similarly, in his Camden conversations with Whitman, Horace Traubel recalled that the poet enjoyed receiving "any letters, provided they are in the true sense human documents." $" 59$ In a manner comparable to Johnson's sense of "compulsion" to correspondence, regardless of return or reciprocity, Whitman related to Traubel that his "main motive" in letter-writing "would be to say things: not to say them prettily - not to stun the reader with surprises - but to say them - to shoot my gun without a flourish and reach the mark if I can." ${ }^{60}$ As he wrote to the soldier Lewis K. Brown in 1863: "my darling boy, when you write to me, you must write without ceremony." 61 Like Johnson in his various symbolic invocations and practices of correspondence, in 'A Backward Glance O'er Travelled Roads' Whitman considered the legacy of his work in terms of the popular contemporary motif of the calling card: "I look upon 'Leaves of Grass,' now finish'd to the end of its opportunities and powers, as my definitive carte visite to the coming generations of the New World, if I may assume to say so."62 Leaves of Grass, he wrote, "is, or seeks to be, simply a faithless and doubtless self-willed record" of "my own physical, emotional, moral, intellectual, and aesthetic Personality [sic], in the midst of, and tallying, the momentous spirit and facts of its immediate days," and, like Johnson in his pop culture collages and continual correspondences, "of current America.",63

\footnotetext{
55 Whitman, 'Crossing Brooklyn Ferry,' 191.

56 Whitman, 'Crossing Brooklyn Ferry,' 191.

${ }^{57}$ Whitman, 'Crossing Brooklyn Ferry,' 191.

${ }^{58}$ Martin, 188.

59 Schmidgall, 123: emphasis added.

60 Edwin Haviland Miller, ed., Selected Letters of Walt Whitman (Iowa City: University of Iowa

Press, 1990), xv.

${ }^{61}$ Haviland Miller, xv.

62 Whitman, 'A Backward Glance O'er Travelled Roads,' 569.

63 Whitman, 'A Backward Glance O'er Travelled Roads,' 569.
} 
Johnson's playful invocation of nothingness to describe his performance work relates closely to his interest in the metonymic and linguistic correpondences inherent in the practice of poetry, perhaps strengthening the appeal of Whitman and his queer poetics. Johnson's creative engagement with poetry arguably began with the 1958 collage 'Gregory Corso Poem,' in which the text is reduced to fragments of words and rearranged, predating Brion Gysin's accidental 'discovery' of the 'cut-up' method that he later shared with Corso, Williams S. Burroughs and many others, at the Parisian 'Beat Hotel' in the summer of 1959. Both recalled the exquisite corpse games and automatic writing practices of the Surrealists. The cut-up, Gysin argued in The Third Mind, an extended exposition of the cut-up written with Burroughs, is not "a literary collaboration but rather the complete fusion in a praxis of two subjectivities [...] that metamorphose into a third; it is from this collusion that a new author emerges, an absent third person, invisible and beyond grasp, decoding the silence." ${ }^{64}$ In these first cut-up experiments, he recalled, "phrases were broken apart, mixed, and combined; the business of disarranging and redistributing the meaning of the message was left to chance. All possibilities of this message were explored." 65 The cut-up was, in both Gysin and Johnson's formulations of it, not opposed to narrative form itself, rather its insistence on chronology and its teleological demands. When asked, in an interview published in The Third Mind, what the distinct features of the cut-up might be, in contrast to those of "conventional narrative," Burroughs responded by asserting that "[a]ny narrative passage or any passage $[\ldots]$ is subject to any number of variations, all of which may be interesting or valid in their own right." 66 Repetitious or compulsive correspondence, as seen in Johnson's mail art, in things to be added to and passed on to others, reflected that same multidirectional temporal motility and narrative inconclusiveness.

In the late 1950s and early 1960s, Johnson designed covers for New Directions editions of work by William Carlos Williams and for Louise Varèse's translation of Arthur Rimbaud's Illuminations. The image of Rimbaud used by Johnson in the New Directions cover in 1957, an appropriation of Etienne Carjat's famous photograph of the poet from 1872, became the basis for a 1971 'mailing event' that was featured in Arts Magazine with the title 'Follow Instructions Below' [Figure 3]. Participants were encouraged to add to the photograph individually, according to instructions given by Johnson, printed over his own appropriated image of Rimbaud: add "words," "a fact," "the name of your favourite person," or "an historic event," disrupting not only traditional associations surrounding the image with trivial personal comments, whose meaning shifted as the piece was mailed on the next participant, but also Johnson's original authorship, as the invitation encouraged creative iconoclasm. ${ }^{67}$ In his own contribution, Johnson wrote across Rimbaud's face that he "went to the movies and ate 32 ice cream sandwiches," a humorous gesture that engaged similar oral, gastronomical themes to his later performance 'Smile,' and in linking the seemingly opposed activities of art making and eating suggested the collapse of any distinction between high art - both its production and its viewing - and the quotidian routine of eating, punning on notions of consumption. In 'Smile,' the oral presence of the peanut butter cups

\footnotetext{
64 William S. Burroughs and Brion Gysin, The Third Mind, (London: J. Calder, 1979), 14.

${ }^{65}$ Burroughs and Gysin, 3.

${ }^{66}$ Burroughs and Gysin, 3.

67 Sharla Shava, 'Determining the Cultural Ecology: Ray Johnson and the New York Corres Sponge Dance School of Vancouver,' How Sad I Am Today: The Art of Ray Johnson and the New York Correspondence School, 23.
} 
works as a pun as it disrupts the aural experience of the reading. The sound of Johnson's chewing, of the cups breaking apart in his mouth, sets up a peculiarly intimate situation in which the viewer becomes aware of the reader's oral activity. The multiple cultural associations surrounding peanut butter were certainly not lost on Johnson. Reese's commercials from the 1970s and 1980s revelled in a reflexiveness and homoerotic suggestiveness that would have undoubtedly pleased Johnson - "you've got your chocolate in my peanut butter," one character exclaims, as the other replies: "you've got your peanut butter in my chocolate." ${ }^{68}$ A Vogue review of Johnson's 1970 show at the Whitney described the exhibition as "nutsy." ${ }^{\circ 9}$ In 1972, Vincent Trasov, the artist who co-founded Image Bank in partial homage to Johnson, appeared on the cover of Vile magazine dressed in a papier mâché nutshell suit as his artistic alter-ego 'Mr Peanut,' a publication that Johnson may very well have seen. There may also have been traces in Johnson's performance of Marcel Proust's madeleine from In Search of Lost Time; a wry take on that archetypal modernist scene of involuntary, gastronomical memory, which had been more explicitly punned by Andy Warhol, with whom Johnson regularly corresponded, in 1955 in the title of his short illustrated book $A$ la recherche $d u$ shoe perdu.

Punned too was the idea of taste; of Whitman's description of correspondence as "a matter of taste," of art institutions as arbiters of 'taste.' ${ }^{70}$ If, as Johnson appeared to suggest, everything is potentially an artwork or a space for display, then traditional notions of 'taste' become useless. In offering 'Smile' as a homage to Whitman, Johnson responded to the rejection of the poet's influence by writers such as Ezra Pound, who struggled in his early career with this "pig-headed father," and winced at what he saw as Whitman's "crudity," which he mercilessly parodied: "Lo! Behold, I eat watermelons." 71 As mail artist Guy Bleus has argued, "the whole point" of correspondence art "was avoidance of selectively curated or juried exhibitions, and with them of taste, hierarchy, competition, fetishism, commodification, reification."72 For Susan Sontag, a play on taste was a central component of that "fugitive sensibility" outlined in her 1964 essay "Notes on Camp., "73 "The experiences of camp," she argued, "are based on the great discovery that the sensibility of high culture has no monopoly upon refinement. Camp asserts that good taste is not simply good taste; that there exists, indeed, a good taste of bad taste."74 But Johnson's performance also looked to critique the aloof commentary of camp, so often associated with Warhol. Like Warhol, Johnson was homosexual, but his manipulation of nothingness owed much more to

\footnotetext{
${ }^{68}$ Reese's Peanut Butter Cups commercial, http://www.youtube.com/watch?v=DJLDF6qZUX0, accessed 18 March 2010.

69 Annmarie Chandler and Norrie Neumark, eds., At a Distance: Precursors to Art and Activism on the Internet (Cambridge, MA: MIT Press, 2005), 96.

70 Traubel, 137.

${ }^{71}$ A later reconciliation appeared in 'A Pact': "It was you that broke the new wood, / Now is a time for carving. / We have one sap and one root - / Let there be commerce between us."

Lee Baechlar and Litz A. Walton, eds., Personae: The Shorter Poems of Ezra Pound (New York: New Directions, 1990), 90.

72 Matt Ferranto, 'Misreading Mail Art,' The Spare Room, http://www.spareroom.org/mailart/mis_intro.html, accessed 18 March 2010.

73 Susan Sontag. 'Notes on Camp,' Fabio Cleto, ed., Camp: Queer Aesthetics and the Performing Subject: A Reader. (Ann Arbor, MI: University of Michigan Press. 1999), 54.

${ }^{74}$ Sontag, 65.
} 
John Cage for whom, as Sharla Shava notes, the "dynamic silence" of Zen philosophy offered another homophile "strategic space." "75 Harold Rosenberg, in The Tradition of the New (1959), argued that all American identity was itself a form of camp: "[a] good deal of the notorious conservatism of the present generation," he wrote, "is ancestor "camping' - that is a dead-pan takeoff on life with Grandpa. In the camp, the masquerade becomes the real thing."76 Shava, too, writes that "[i]n the noisy circulation of the New York Correspondence School, nothing, not even the irreverent detachment so prized in camp, was sacred." 77 In his performance, Johnson suggests Whitman as an alternative queer forefather - "Grandpa" - tasteless and exuberant, critiquing both the 'camp' of Warhol, and the problem of cultural inheritance, of 'the tradition of the new.'

In 'Smile,' through the melting of the peanut butter cups, Whitman's words become temporarily "unintelligible."78 In reading from the earlier poet's thoughts on "personal" correspondence much of which, in Whitman's case, consisted of what we might call romantic letters to young men - Johnson calls attention to questions of hidden, or coded, homosexual desire in Whitman's work, to its resonances with his own homosexuality, and also to the re-interpretation and embrace of Whitman's work in the later twentieth century by literary groups like the San Franciscobased Gay Sunshine Press, and writers like Allen Ginsberg and Jack Kerouac. ${ }^{79}$ To quote again from William Wilson: "[Johnson] knows more than we can immediately understand until he has mashed something [-] what else does he know that we don't know, and that we can correctly perceive only sections of?" ${ }^{80}$ It is what Michael Warner has called, with reference to Whitman, the intimate, "mutual non-knowledge" between author and reader. "This hour I tell things in confidence," Whitman wrote in 'Song of Myself,' "I might not tell everybody, but I will tell you." 82 We might compare, then, Johnson's performance to David Hockney's paintings on the theme of Whitman's cruising, for example Adhesiveness (1960) [Figure 4] and We Two Boys Together Clinging (1961), in which the visual languages of figuration and abstraction collide in what Hockney called a "double portrait" through which, like Johnson, Hockney was reacting to an Abstract Expressionist model of virile male heterosexuality by applying homosexual figures to a flatly painted background of solid colour. In contrast to Allan Kaprow's spirited embrace of Pollock's creative legacy in the late 1950s, Allen Ginsberg, in an interview with Allen Young for the journal Gay Sunshine in 1972, put Whitman, and in particular 'We Two Boys Together Clinging,' at the head of his own canon of influences, his "line of transmission" wherein "the older person made love to the younger person, blew the younger person, and there was the absorption of the

\footnotetext{
75 Shava, 23.

${ }^{76}$ Harold Rosenberg, The Tradition of the New (New York Da Capo Press. 1959), 242: emphasis added.

77 Shava, 23.

78 Suiter, n.p.

${ }^{79}$ See Charles Shiveley, ed., Drum Beats:Walt Whitman's Civil War Boy Lovers (San Francisco, CA: Gay Sunshine Press. 1989)

${ }^{80}$ Suiter, n.p.

${ }^{81}$ Michael Warner, 'Whitman Drunk,' Betsy Erkilla, and Jay Grossman, eds., Breaking Bounds: Whitman and American Cultural Studies (New York; Oxford: Oxford University Press. 1996), 41.

82 Whitman, 'Song of Myself,' Complete Poems, 81.
} 
younger person's electric vital magnetism." ${ }^{83}$ This line was, as Ginsberg explained, "an ancient thing" [...] it's very old and very charming for older and younger to make it" and he was eager to join in this neo-Grecian practice, sleeping with Gavin Arthur who "had slept with Edward Carpenter who had slept with Whitman," thus "[receiving] the Whispered Transmission [...] of that love." ${ }^{84}$ As in Johnson's performance of 'Smile,' each artist reinvigorated the other's practice orally and each exceeded their own temporal circumstances to interact erotically across time.

In his study on montage and collage practices in the "allegorical" Dada work of George Grosz, Benjamin Buchloch argued that for Grosz collage functioned "in such a way as to say in pictures what would have been banned by the censors if we had said it in words." 85 "From the very moment of its inception," Buchloch noted, "it seems that the inventors of the strategy of montage were aware of its inherently allegorical nature: 'to speak publicly with hidden meaning." "86 Johnson's correspondence art enacted a similar performance of silence; an ontological 'nothingness' that was resistant to commodification and reified 'thingness.' Jonathan D. Katz has argued that the "silence" of artists like Robert Rauschenberg, as enacted in his White Paintings (1951), glossy, monochrome canvases that reflect the outlines of passing viewers and adjacent works of art, and John Cage, in his environmental 'silent' composition 4'33" (first performed in 1952), was not "passive resistance," but rather, "a specularized, performative and highly ironized silence - a form of political engagement" and a "strategy of dissent" in the oppressive environment of McCarthyite America, in which homosexuality was pathologised and routinely censured by state and federal legislature. ${ }^{87}$ Thus we might read the unintelligibility of Johnson's work and its friendly metonymic contingencies, in both his correspondence pieces and in a more literal sense in 'Smile,' as an embrace of those practices which emerged to assist queer artists to escape censure or censorship and recalled Whitman's own secretive practice of applying numerical codes to men he had cruised or was sexually attracted to. As John Cage recalled, in the 1950s, correspondence was still one of the only creative social practices that could potentially remain private: "[c]onversation was difficult and correspondence virtually ceased. (not because of the mails, which continued.) People spoke of, perhaps because they'd not heard from one another in a long time. Art flourished." ${ }^{88}$ Acts of reworking, recoding and rerouting the cultural material of everyday life were key to Johnson's collage and performance practices and their reworking of dominant culture outputs. As Judith Butler noted of the theoretical and political reclaiming of the term

${ }^{83}$ Allen Young, 'Interview with Allen Ginsberg,' Winston Leyland, ed., Gay Sunshine Interviews: Volume 1 (San Francisco: Gay Sunshine Press, 1978), 106 - 107.

${ }^{84}$ Young, 'Interview with Allen Ginsberg,' 106.

${ }^{85}$ Benjamin Buchloch, 'Allegorical Procedures: Appropriation and Montage in Contemporary Art', Artforum (October 1982), 43.

${ }^{86}$ Buchloch, 43.

87 Jonathan D. Katz, 'The Silent Camp: Queer Resistance and the Rise of Pop Art,' http://www.queerculturalcenter.org/Pages/KatzPages/KatzCamp.html, accessed 18th March 2010

For a more detailed account of the treatment of homosexuality in the United States during the 1950s, see David K. Johnson, The Lavender Scare: The Cold War Persecution of Gays and Lesbians in the Federal Government (Chicago: University of Chicago Press, 2009)

${ }^{88}$ Katz, n.p. 
'queer' in the late 1980s and early 1990s, that which once "signalled degradation has been been turned $[\ldots]$ to signify a new and affirmative set of meanings." 89

In the early 1960s in England, David Hockney was working on something similar, incorporating into paintings such as Adhesiveness "Whitman's numerical code for documenting young men that he met on the streets of the city, the code that was cracked in 1950," turning Whitman's shame on its head in "playful appropriation." 90 Adhesiveness is not a full or conclusive portrait of either Hockney or Whitman. Both are shaped by interpretations of the other and by their connection. In Adhesiveness Hockney evokes the recognisable motifs of Abstract Expressionism explicitly and applies queerness to his paintings in a coded manner so that the homoerotic dimension is not be immediately apparent; it emerges over time and in socio-sexually distinct contexts, as Whitman's sexuality has appeared to later readers. Like Johnson's performance and correspondence pieces, the work does not offer a code that must be cracked, rather, it alludes to "a chosen mode of resistance" that would "serve to open up the process of signification." 91 As Katz argues, "silence isn't the opposite of sound, nor blankness the opposite of gesture, but rather an element within it." 92 Similarly, Peter Coviello has argued that those texts

in which we discover that Whitman's great secret is, after all, his desire for men; that Whitman's homoerotic attachments need to be rescued from the guardians of the canon who want only to expurgate him; that by his secret codes (which we have cracked) the poet means to outfox and finally redeem a repressive nation [...] offer little new insight into the complexity of Whitman's corpus. ${ }^{93}$

Just as Hockney's painting does not try to crack Whitman's code, but offers a thoughtful, knowing nod to it, the punning humour of 'Smile' drew on the hidden homoerotic intimacies of Whitman's letters, and speaks to Johnson's desire to join the correspondence games led by the young gay men behind General Idea and the Image Bank, Vile and File megazine, but not to be historicised by them; que(e)rying this persistent notion of canonical patriarchy that too closely recalled the grandiose modernism of Clement Greenberg and the Abstract Expressionists, that Johnson worked hard to critique, humorously, but vehemently. In an interview with Harper's Bazaar in the early 1950s, Johnson was asked what kind of artist he was and he replied: "When I go walk-

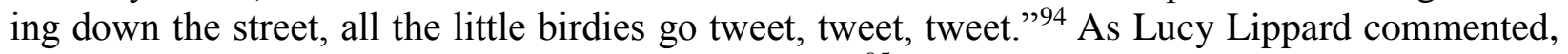
"this did not exactly ensure his place in art history." 95 Like much of Johnson's correspondence works, this was a camp gesture that through its unintelligibility, ensured, somewhat ironically, that the interpretation and reception of his work remained fluid, appropriately aleatory, or at least multiplicitious.

${ }^{89}$ Judith Butler, Bodies that Matter (London: Routledge, 1993), 169.

${ }^{90}$ Mark Turner, Backward Glances: Cruising the Queer Streets of New York and London (London: Reaktion Books, 2003), 145.

${ }^{91}$ Katz, n.p.

92 Katz, n.p.

93 Peter Coviello, Intimacy in America: Dreams of Affiliation in Antebellum Literature (Minneapolis, MN: University of Minnesota Press, 2005), 211.

94 Lucy Lippard, 'Special Deliverance,' de Salvo and Gudis, 142.

95 Lippard, 142. 
Johnson committed suicide on Friday the 13th of January 1995, jumping off a bridge and drowning at Sag Harbour. As William Wilson noted of 'Smile,' "Ray sees, reads and knows more than can be communicated in his art" 96 and he appeared to have relished the opportunity for an unusual departure. An article in the British Independent newspaper compared his death to a line in Whitman's poem 'As I Ebb'd with the Ocean of Life': "floating the measureless float"; a final 'nothing. ${ }^{97}$ After 'Smile,' Johnson had worked on a series of drawings of famous people's bathtubs, in which Whitman was included, "even though," Henry Martin noted, "Whitman didn't have a bathtub." 98 Like his collages, Johnson's performances accreted meaning across a lifetime, their content and meaning "self-proliferating" beyond feasible explanation into multiple possibilities, all intentionally inexplicable. ${ }^{99}$ Personal histories, genealogies and artistic lineages behave in both Whitman and Johnson's creative practices in a fundamentally fluid manner. In 'Smile'"s playful appropriation of collage and correspondence practices lie suggestions for a methodology of counter-history that respects and mimics the non-normative narrative of queer life, its (a)chronology, rather, a "trail of drift and debris." 100 As Judith Butler asserted in the closing chapter of Bodies that Matter: "[i]f 'queer' is to be a site of collective contestation, the point of departure for a set of historical reflections and future imaginings, it will have to remain that which is never fully owned, but always redeployed, twisted, queered from a prior usage." 101 These queer correspondences are, like Johnson's practice, Whitmanesque, but fatherless. They point to Whitman's influence on the irreverent Johnson, while rejecting the restrictions of a chronological chain of influence, much as Johnson's earlier mail art had done. As Whitman himself urged Horace Traubel at Camden: "whatever you do, do not prettify me."102

\footnotetext{
96 Suiter, n.p.

97 Suiter, n.p.

${ }^{98}$ Martin, 185.

99 Martin, 185.

100 Whitman, 'As I Ebb'd with the Ocean of Life.,' Complete Poems, 283.

101 Butler, 228: emphasis added.

102 Traubel, ix.
} 


\section{List of Illustrations}

Figure 1. Screenshot from Smile, 1987.

Figure 2. Ray Johnson, Elvis \#1, 1956-7

Figure 3. Ray Johnson, 'Follow Instructions Below,' Arts Magazine (November 1971), pp. $42-44$

Figure 4. David Hockney, Adhesiveness, 1960 